\title{
Toward a Poetics of Genesis I-II
}




\title{
Bulletin for Biblical Research Supplements
}

\author{
Editor \\ Richard S. Hess, Denver Seminary \\ Associate Editor \\ Craig L. Blomberg, Denver Seminary \\ Advisory Board
}

Leslie C. Allen

Fuller Theological Seminary

Donald A. Carson

Trinity Evangelical Divinity School

Donald A. Hagner

Fuller Theological Seminary

Karen H. Jobes

Wheaton College

\author{
I. Howard Marshall \\ University of Aberdeen \\ Elmer A. Martens \\ Mennonite Brethren Biblical \\ Seminary \\ Bruce K. WaltKe \\ Knox Theological Seminary \\ EDWIN M. YAMAUCHI \\ Miami University
}

I. Bridging the Gap: Ritual and Ritual Texts in the Bible, by Gerald A. Klingbeil

2. War in the Bible and Terrorism in the Twenty-First Century, edited by Richard S. Hess and Elmer A. Martens

3. Critical Issues in Early Israelite History, edited by Richard S. Hess, Gerald A. Klingbeil, and Paul J. Ray Jr.

4. Poetic Imagination in Proverbs: Variant Repetitions and the Nature of Poetry, by Knut Martin Heim

5. Divine Sabbath Work, by Michael H. Burer

6. The Iron Age I Structure on Mt. Ebal: Excavation and Interpretation, by Ralph K. Hawkins

7. Toward a Poetics of Genesis I-II: Reading Genesis 4:I7-22 in Its Near Eastern Context, by Daniel DeWitt Lowery 


\title{
Toward a Poetics of Genesis I-II \\ Reading Genesis 4:I7-22 in Its \\ Near Eastern Context
}

\author{
Daniel DeWitt Lowery
}

Winona Lake, Indiana

Eisenbrauns $2 \mathrm{OI} 3$ 
(C) Copyright 2013 Eisenbrauns

All rights reserved.

Printed in the United States of America.

www.eisenbrauns.com

\section{Library of Congress Cataloging-in-Publication Data}

Lowery, Daniel DeWitt.

Toward a poetics of Genesis I-II : reading Genesis 4:I7-22 in its Near Eastern context / by Daniel DeWitt Lowery.

pages $\mathrm{cm}$.

(Bulletin for biblical research supplements ; 7)

Includes bibliographical references and index.

ISBN 978-I-57506-8I6-9 (hardback : alk. paper)

I. Bible. O.T. Genesis IV, I7-24-Criticism, interpretation, etc.

I. Title.

BSI235.52.L69 2013

$222^{\prime} .1106-\mathrm{dc} 23$

2013001282

The paper used in this publication meets the minimum requirements of the American National Standard for Information Sciences - Permanence of Paper for Printed Library Materials, ANSI Z39.48-I984. @TM 